\title{
Ecological Sound Control Strategies for Population Suppression of Date Palm Borers Oryctes spp.
}

\author{
Mohammed Zaidan Khalaf ${ }^{1}$, Hussain Fadhel Alrubeai ${ }^{1}$, Mohammed Waleed Khudhaer ${ }^{1}$ and Aysar Abdulkarem \\ Abdulhusein ${ }^{2}$ \\ 1. Integrated Pest Control Research Center, Directorate of Agricultural Research, Ministry of Science \& Technology, Baghdad \\ 00964, Iraq \\ 2. Directorate of Baghdad Agriculture, Ministry of Agriculture, Baghdad 00964, Iraq
}

\begin{abstract}
Cultural practices, hand collection of larvae, light traps and entomopathogenic fungi were investigated to manage of palm borers Oryctes spp. in date palm orchards during the years 2010-2015. Cultural practices, such as sanitation and pruning frond bases, hand collection of larvae during regular annual service work and light traps with solar energy were practiced annually in one orchard for five years. In the second orchard, cultural practices were applied for two years, light trap for one year only, and no hand collection of larvae was done during the period. The third orchard was used as a control treatment. Results showed reduction in population density of larvae ( $91.6 \%$ and $53.0 \%)$ and adult $(76.1 \%$ and $41.1 \%)$ of Oryects spp. in the 1 st and 2 nd orchard, respectively. The results also demonstrated the impact of moon light phases on the number of Oryctes spp. adults caught by light trap and the existence of an inverse relation between moon light and flight activity of adults. Biological experiments also revealed that entomopathogenic fungi can cause high mortality rate reaching $100 \%$ after $29 \mathrm{~d}$. Beauveria bassiana scored higher mortality rate in short time, especially at concentration of $1 \times 10^{11}$ conidia/mL with $\mathrm{LT}_{50}=12.75$ and $\mathrm{LT}_{90}=20$; while, Metarhizium anisopliae caused the higher percentage of malformed adults. The results depicted the effectiveness of some integrated ecological sound control methods for monitoring and population suppression of Oryects spp. in date palm orchards.
\end{abstract}

Key words: Integrated pest management, cultural practices, hand collection of larvae, light traps, moon light, entomopathogenic fungi, Oryects spp..

\section{Introduction}

Date palm tree, Phoenix dactylifera is one of the major crops in Iraq and most adapted to climatic conditions of the region [1, 2]. It suffers damages from several pests, especially borers, like palm frond borer-Phonapate frontalis, long horn palm stem (trunk) borer-Jebusaea hammerschmidtii and several Oryctes spp., fruit stalk (bunch) borer-Oryctes elegans and Oryctes agamemnon, Arabian rhinoceros beetle-Oryctes agamemnon arabicus and Oryctes agamemnon matthisseni which are widely spread in date palm orchards of Iraq and other countries [3-7].

Oryctes spp. complex caused severe damages to the

Corresponding author: Mohammed Zaidan Khalaf, Ph.D., research fields: entomology, integrated pest management of palm and citrus pests. bases of fronds and bunches, making long tunnels inside tissue, which acting as weakening and breaking factors for these parts [8-10]. By boring and feeding on plant tissue, it thus leads to infection with pathogens, and the associated plant weakness and low productivity $[2,11,12]$. Ecological beginning control measures play an important role as a solution responding to the economic, sanitary and environmental requirements. Such practices as a major component of integrated pest management (IPM) strategy can conserve the biodiversity by natural balance and minimizing and rationalizing to pesticide use [13].

The possibility of using light traps in management strategy of insect and date palm borers has been pointed out in many researches [14-16]. This study aimed to suppress population density of Arabian 
rhinoceros beetle-Oryctes agamemnon arabicus in Iraqi date palm orchards, through application some of ecological sound control methods.

\section{Materials and Methods}

Three integrated pest management techniques were administered in field to evaluate its efficacies to suppress the population density of Oryects spp. in date palm orchards (1 ha each) located in Almadain district according to global positioning system (GPS) with latitude $33^{\circ} 15^{\prime}$ north, longitude $44^{\circ} 56^{\prime}$ east $(30 \mathrm{~km}$ south of Baghdad), where common date varieties (Barhee, Brem, Umrani, Khastawi and Zahdi) were contained, during the years 2010-2015. The control options were conducted as the following:

(1) In first orchard experience, cultural practices (pruning frond bases as annual regular service work in date palm orchards), hand collection of larvae and light trap were done for adults capture for five years period;

(2) In the second orchard experience, cultural practices were applied for two years 2010 and 2012, collecting adults by light trap for one year 2010 only, while no hand collection of larvae was practiced for in five years period;

(3) The third orchard was used as a control treatment, that is mean no cultural practices, no hand collection of larvae and no light trap were practiced in five years period. The Oryctes spp. larvae were collected and counted from the crown of palm tree during annual sanitation practices starting in January till March of each orchard. The numbers of Arabian rhinoceros beetle (ARB) adults were counted daily in each light trap during June and July to determine the population density of adults in each orchard.
Meanwhile, Sony HD-R 50 camera was used to image the daily moon phases through the period from June $13-14$ to July $12-13$ in 2010 , June $18-19$ to July $17-18$ in 2015 to measure the effect of moon light intensity on adults flight ability. In addition, two local entomopathogenic isolates were tested in laboratory for their pathogencity against Oryctes larvae, which are MARD 34 and MARD 46 (Table 1) selected from Entomopathogenic Fungal Isolates Bank at the Agricultural Research Directorate, Iraqi Ministry of Science and Technology [17].

The spore concentrations were determined using haemocytometer and adjusted to $1 \times 10^{5}, 1 \times 10^{7}, 1 \times$ $10^{9}$ and $1 \times 10^{11}$ conidia $/ \mathrm{mL}$. The four concentrations were applied separately by direct spraying of each on the larvae and on their food. Three replicates (five larvae each) were used for each treatment. Borer larvae in each replicate were transferred into new sterilized cage $30 \mathrm{~cm} \times 20 \mathrm{~cm} \times 22.5 \mathrm{~cm}$. Cages were kept under rearing room conditions $\left(25 \pm 2{ }^{\circ} \mathrm{C}\right.$ and $70 \%$ relative humidity), and they were checked every $3 \mathrm{~d}$, counting the dead larvae along with monitor their behavior and any noticeable morphological changes.

\section{Results and Discussion}

\subsection{Cultural Practices and Hand Collection of Larvae as a Control Methods}

The results in Table 2 indicated the efficacy of cultural practices (sanitation and pruning fronds bases) and hand collection of larvae during annual regular service work in date palm orchards in reducing the population density of Oryctes spp.. The number of collected larvae reduced from 9.5 to 0.8 and from 10.9 to 5.1 per tree crown in the 1 st and 2 nd orchards during

Table 1 Isolates of Metarhizium anisopliae and Beauveria bassiana used.

\begin{tabular}{|c|c|c|c|c|c|}
\hline Isolate code & Species & Location & Longitude & Latitude & Isolation source \\
\hline MARD 34 & $\begin{array}{l}\text { Metarhizium } \\
\text { anisopliae }\end{array}$ & $\begin{array}{l}\text { Basra } \\
\text { province }\end{array}$ & $47^{\circ} 77^{\prime}$ east & $30^{\circ} 68^{\prime}$ north & $\begin{array}{l}\text { Infected adult of O. agamemnon } \\
\text { arabicus in date palm and citrus orchard }\end{array}$ \\
\hline MARD 46 & Beauveria bassiana & $\begin{array}{l}\text { Thi Qar } \\
\text { province, } \\
\text { Nisria city }\end{array}$ & $46^{\circ} 48^{\prime}$ east & $31^{\circ} 13^{\prime}$ north & Date palm, orchard soil \\
\hline
\end{tabular}


Table 2 Effect of integrated control measures on population density of Oryctes spp. larvae on date palm orchards in five years period 2010-2015.

\begin{tabular}{|c|c|c|c|c|c|c|}
\hline \multirow{3}{*}{ No. of tree } & \multicolumn{6}{|c|}{ Larva per tree ( in crown only) at year $2010-2015$} \\
\hline & \multicolumn{2}{|c|}{ Orchard No.1 } & \multicolumn{2}{|c|}{ Orchard No.2 } & \multicolumn{2}{|c|}{ Orchard No.3 } \\
\hline & 2010 & 2015 & 2010 & 2015 & 2010 & 2015 \\
\hline 1 & 7 & 0 & 13 & 5 & 10 & 12 \\
\hline 2 & 4 & 1 & 12 & 4 & 9 & 29 \\
\hline 3 & 12 & 0 & 11 & 3 & 13 & 31 \\
\hline 4 & 15 & 0 & 12 & 5 & 14 & 19 \\
\hline 5 & 10 & 2 & 15 & 2 & 14 & 28 \\
\hline 6 & 13 & 0 & 9 & 6 & 12 & 22 \\
\hline 7 & 12 & 2 & 12 & 2 & 13 & 18 \\
\hline 8 & 14 & 1 & 6 & 7 & 14 & 16 \\
\hline 9 & 8 & 1 & 9 & 8 & 9 & 17 \\
\hline 10 & 9 & 1 & 10 & 9 & 10 & 25 \\
\hline Total & 95 & 8 & 109 & 51 & 118 & 217 \\
\hline Mean & 9.5 & 0.8 & 10.9 & 5.1 & 11.8 & 21.7 \\
\hline Reduction (\%) & \multicolumn{2}{|c|}{$91.6 \%$} & \multicolumn{2}{|c|}{$53.0 \%$} & \multicolumn{2}{|c|}{-} \\
\hline
\end{tabular}

2010 and 2015, respectively, in comparison with 11.8 to 21.7 in the 3rd orchard (control). Obviously, the control practices applied decreased the population density of larvae year after year from 2010 to 2015 . Such reduction represents in values of $91.6 \%$ and $53.0 \%$ for the $1 \mathrm{st}$ and 2 nd orchards, respectively, compared with the control orchard. The results of the control orchard showed the increase in larval number from total 118 larvae in 2010 to 217 larvae in 2015, which is almost two time higher. Such results clearly demonstrated the efficacy of the administered management practices, which could be applied routinely during annual services of date palm orchards. These results are in agreement with the finding of Khalaf et al. [18] on Oryctes elegans in Iraq date palm orchards.

\subsection{Light Traps as a Control Method of Adults}

The results in Table 3 showed that the total adults of Oryctes spp. caught during season of 2010 were 134, 157 and 139 adults per trap per month in the 1st, 2nd and 3rd orchards, respectively. While, after five years of using light traps to monitor and control, the numbers of adults caught reached 32, 93 and 237 adult per trap per month. These values represent a reduction in adults population of $71.1 \%$ in the 1 st orchard after five years of annually cultural practices, hand collection of larvae and light trap during the whole period of experiment and $41.1 \%$ in the 2 nd orchard (cultural practices each two years, 2010 and 2012 and light trap for one year 2010, without application of larval collection during the whole period of experiment), compared with the 3rd orchard (as a control treatment). It is obvious that management practices decreased the population density of Oryctes spp. adults after five years. It is worth mentioning that the number of captured adults decreased gradually till it reached the lowest number in mid of Islamic month (11-20) and increased gradually again from 21-30 in last final $10 \mathrm{~d}$ of Islamic month, which could be the effect of moon light on flight ability of adults. These results are in agreement with the finding by Khalaf et al. [2, 18], when they used light traps to monitor and control of $O$. elegans in Iraq date palm orchards.

The results in Fig. 1 showed that the relation between moon phase light intensity and flight ability of Oryctes spp. adults. Results showed that the numbers of adults caught in trap were affected negatively by the light intensity (full moon). Adults number caught were 19, 32 and 26 adult in the 1 st, 2nd and 3rd orchards, respectively, compared with 39:76, $48: 77$ and 42:71 during the first (moon age 1-10 
Date Palm Borers Oryctes spp.

Table 3 No. of Oryctes spp. adults caught in light traps in date palm orchards at seasons of 2010-2015.

\begin{tabular}{|c|c|c|c|c|c|c|c|c|c|}
\hline \multirow{2}{*}{\multicolumn{4}{|c|}{ Observed date and moon phase }} & \multicolumn{6}{|c|}{ Number of Oryctes spp. adults } \\
\hline & & & & \multicolumn{2}{|c|}{ Orchard No.1 } & \multicolumn{2}{|c|}{ Orchard No. 2} & \multicolumn{2}{|c|}{ Orchard No.3 } \\
\hline Islamic month & Moon phase & $\begin{array}{l}2010 \\
\text { June/July }\end{array}$ & $\begin{array}{l}2015 \\
\text { June/July }\end{array}$ & 2010 & 2015 & 2010 & 2015 & 2010 & 2015 \\
\hline $1 / 2$ & & $13 / 14$ & $18 / 19$ & 6 & 2 & 7 & 5 & 6 & 13 \\
\hline $2 / 3$ & & $15 / 15$ & $19 / 20$ & 5 & 1 & 6 & 4 & 5 & 13 \\
\hline $3 / 4$ & & $15 / 16$ & $20 / 21$ & 4 & 2 & 6 & 3 & 6 & 12 \\
\hline $4 / 5$ & & $16 / 17$ & $21 / 22$ & 4 & 1 & 5 & 4 & 6 & 12 \\
\hline $5 / 6$ & & $17 / 18$ & $22 / 23$ & 5 & 1 & 4 & 3 & 2 & 10 \\
\hline $6 / 7$ & & $18 / 19$ & $23 / 24$ & 2 & 0 & 4 & 3 & 2 & 6 \\
\hline $7 / 8$ & & $19 / 20$ & $24 / 25$ & 4 & 1 & 6 & 3 & 5 & 7 \\
\hline $8 / 9$ & & $20 / 21$ & $25 / 26$ & 3 & 0 & 4 & 2 & 5 & 4 \\
\hline $9 / 10$ & & $21 / 22$ & $26 / 27$ & 3 & 1 & 3 & 2 & 2 & 3 \\
\hline $10 / 11$ & & $22 / 23$ & $27 / 28$ & 3 & 1 & 3 & 2 & 3 & 3 \\
\hline $11 / 12$ & & $23 / 24$ & $28 / 29$ & 3 & 0 & 2 & 0 & 2 & 1 \\
\hline $12 / 13$ & & $24 / 25$ & $29 / 30$ & 0 & 1 & 2 & 1 & 2 & 3 \\
\hline $13 / 14$ & & $25 / 26$ & $30 / 1$ & 2 & 0 & 4 & 3 & 3 & 5 \\
\hline $14 / 15$ & & $26 / 26$ & $1 / 2$ & 2 & 0 & 5 & 3 & 3 & 3 \\
\hline $15 / 16$ & & $27 / 28$ & $2 / 3$ & 1 & 1 & 3 & 2 & 2 & 0 \\
\hline $16 / 17$ & & $28 / 29$ & $3 / 4$ & 0 & 0 & 2 & 0 & 2 & 3 \\
\hline $17 / 18$ & & $29 / 30$ & $4 / 5$ & 2 & 0 & 3 & 1 & 2 & 3 \\
\hline $18 / 19$ & & $30 / 1$ & $5 / 6$ & 2 & 1 & 3 & 0 & 2 & 4 \\
\hline $19 / 20$ & & $1 / 2$ & $6 / 7$ & 3 & 1 & 3 & 2 & 3 & 0 \\
\hline $20 / 21$ & & $2 / 3$ & $7 / 8$ & 4 & 1 & 5 & 1 & 5 & 3 \\
\hline $21 / 22$ & & $3 / 4$ & $8 / 9$ & 3 & 0 & 5 & 2 & 4 & 6 \\
\hline $22 / 23$ & & $4 / 5$ & $9 / 10$ & 3 & 0 & 7 & 3 & 6 & 8 \\
\hline $23 / 24$ & & $5 / 6$ & $10 / 11$ & 6 & 1 & 7 & 4 & 7 & 12 \\
\hline $24 / 25$ & & $6 / 7$ & $11 / 12$ & 6 & 1 & 8 & 5 & 6 & 14 \\
\hline $25 / 26$ & & $7 / 8$ & $12 / 13$ & 7 & 2 & 6 & 6 & 5 & 14 \\
\hline $26 / 27$ & & $8 / 9$ & $13 / 14$ & 8 & 2 & 8 & 4 & 8 & 13 \\
\hline $27 / 28$ & & $9 / 10$ & $14 / 15$ & 10 & 3 & 8 & 5 & 9 & 17 \\
\hline $28 / 29$ & & $10 / 11$ & $15 / 16$ & 11 & 2 & 9 & 5 & 8 & 14 \\
\hline $29 / 30$ & & $11 / 12$ & $16 / 17$ & 12 & 3 & 9 & 7 & 8 & 16 \\
\hline $30 / 1$ & & $12 / 13$ & $17 / 18$ & 10 & 3 & 10 & 8 & 10 & 15 \\
\hline Total & & & & 134 & 32 & 157 & 93 & 139 & 237 \\
\hline Mean & & & & 4.5 & 1.1 & 5.2 & 3.1 & 4.6 & 7.9 \\
\hline Reduction (\%) & & & & & & & & & \\
\hline
\end{tabular}




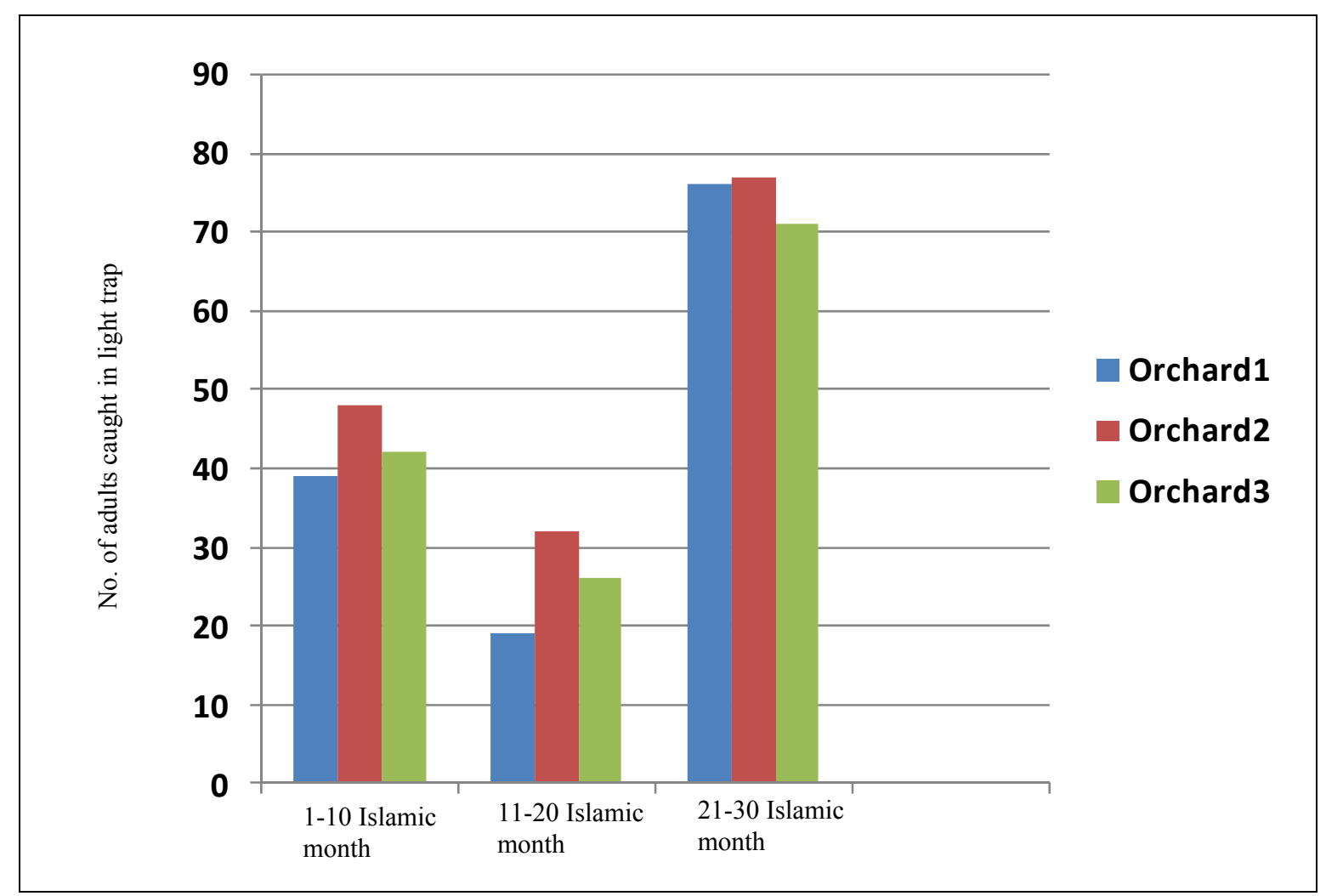

Fig. 1 Effect of moon light on flight ability of Oryctes spp. in date palm orchards.

day):last 10 day (moon age 21-30 day) in the 1st, 2nd and 3rd orchards, respectively (Fig. 1). These results indicated a relation between the flight ability of Oryctes spp. adults and moon light intensity. These result matches with those found by Khalaf et al. [2], Steibaner [15] and Morton et al. [19] about impact of brightness of the moon light on Oryctes elegans, Heliothis armigera and Mnesampela privata caught in light traps.

\subsection{Efficacy of Entomopathogenic Fungi on Oryctes spp. Larvae}

Survival percentages of Oryctes spp. larvae after treating them with entomopathogenic fungal isolate $B$. bassiana MARD 46 spore suspensions revealed that the concentration $1 \times 10^{11}$ conidia $/ \mathrm{mL}$ inflicted the highest mortality among larvae, reaching $93.33 \%$ after $19 \mathrm{~d}$, followed by the concentration $1 \times 10^{9}$ conidia $/ \mathrm{mL}$ that recorded mortality of $66.66 \%$ at the same time (Fig. 2). In addition, mortality reached $53.33 \%$ after $19 \mathrm{~d}$ using concentration of $1 \times 10^{7}$ conidia $/ \mathrm{mL}$ and the lowest mortality was $40 \%$ at the concentration $1 \times 10^{5}$ conidia $/ \mathrm{mL}$ after the same period. All concentrations used decreased larval survivals with time progression, reaching $0 \%$ at the end of the experiment ( $29 \mathrm{~d}$ ).

Fig. 3 illustrates survival percentages of date palm borers' larvae during experiment duration (29 d) following treatment with different spore suspension concentrations of $M$. anisopliae (MARD 34). The result revealed that the highest mortality after $19 \mathrm{~d}$ was $66.66 \%$ at concentration $1 \times 10^{11}$ conidia $/ \mathrm{mL}$, followed by the concentration $1 \times 10^{9}$ conidia $/ \mathrm{mL}$ with $53.33 \%$ at the same time. The lowest mortality scored at the concentrations $1 \times 10^{5}$ conidia $/ \mathrm{mL}$ and 1 $\times 10^{7}$ conidia $/ \mathrm{mL}$, reaching $46.66 \%$ after $19 \mathrm{~d}$ of the treatment. All concentration recorded decrease of survival with time progression, reaching $0 \%$ at the end of the experiment.

Ricano et al. [20] found that using more than one formula of $B$. bassiana can remarkably reduce survival and increase mortality rate among red palm 


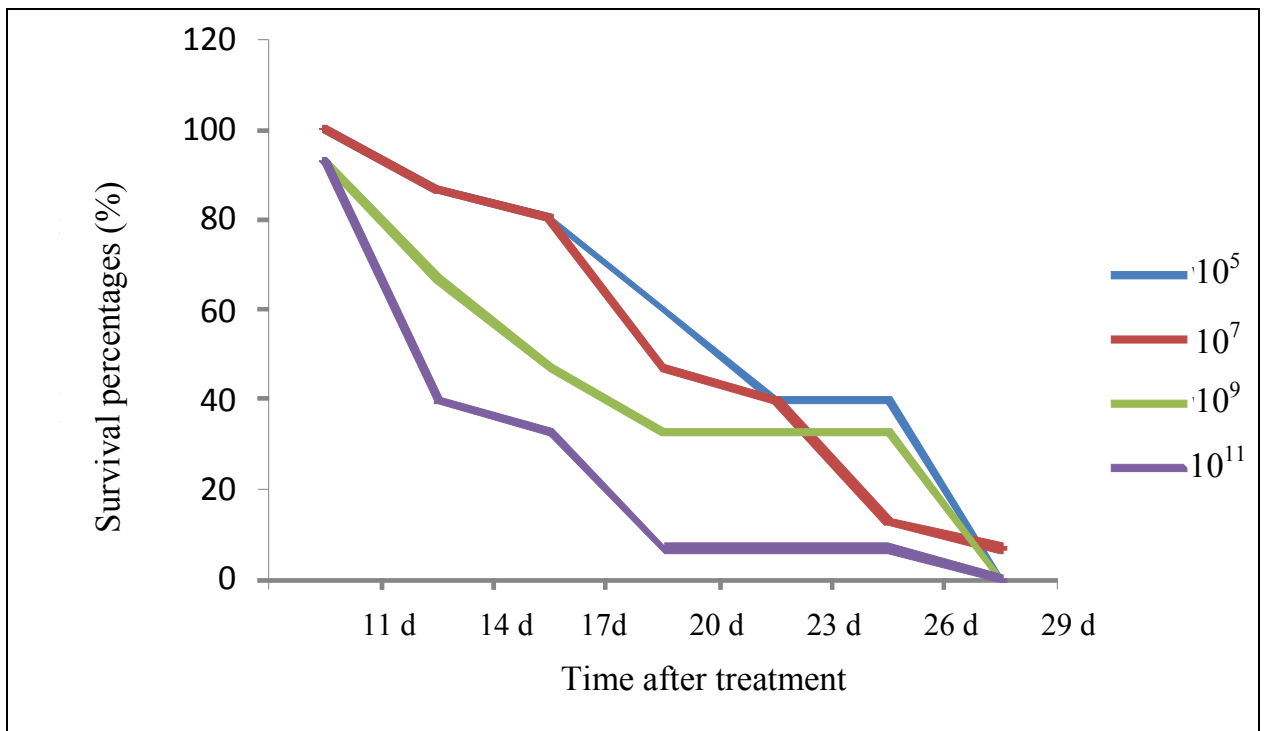

Fig. 2 Survival percentages among date palm borer larvae Oryctes spp. treated with the Beauveria bassiana isolate (MARD46).

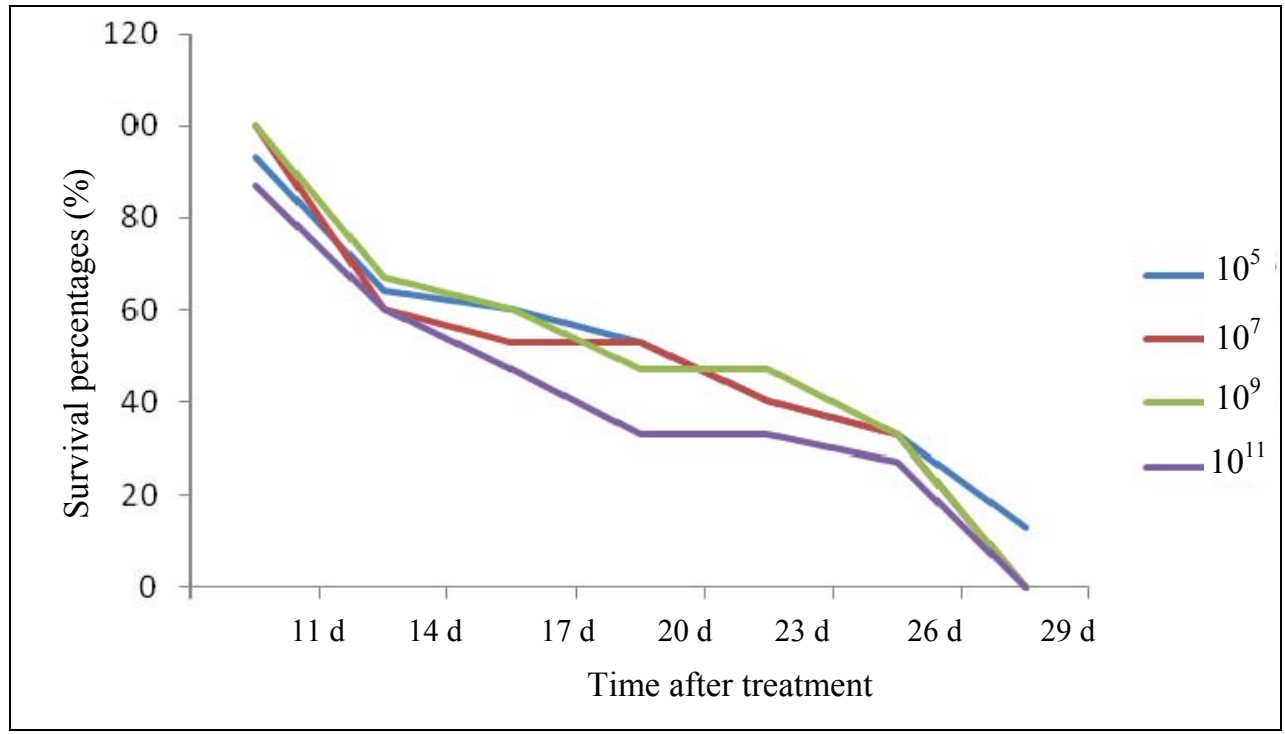

Fig. 3 Survival percentages among date palm borer larvae Oryctes spp. treated with the Metarhizium anisopliae isolate (MARD34).

weevil larvae and adults. B. bassiana can increase mortality rate of Helicoverpa armigera larvae as well as mentioned by Ritu et al. [21]. Such practice, using entomopathogenic fungi infested of conventional insecticides which failed in achieving acceptable control level, could be effective alternative and sound method from ecological and health view points.

\section{Conclusions}

In conclusion, the results demonstrated the high infestation rates of Oryctes spp. to date palm trees. Application of cultural practices, hand collection of larvae, light traps for adults and entomopathogenic fungi as ecological sound pest management practices showed clearly the efficacies of such practices to control of Oryctes spp. (especially Oryctes agamemnon arabicus as a dominant species in Iraq) in date palm orchards. Therefore, the approach of these practices is recommended to manage and control palm borer annually. 


\section{References}

[1] Hussain, A. A. 1974. Date Palm and Dates with Their Pest in Iraq. Iraq: University of Baghdad, 166.

[2] Khalaf, M. Z., Shbar, A. K., Al-Seria, M. H., Sami, R. A., and Naher, F. H. 2011. "Some Aspects of Biology and Control Methods of Fruit Stalk Borer Oryctes elegans Prell (Coleoptera: Scarabaeidae)." Journal of Agricultural Science \& Technology A 1: 142-7.

[3] Khalaf, M. Z., Naher, F. H., and Ali, A. A. 2010. "Population Density of Oryctes elegans Prell (Coleoptera: Scarabaeidae) on Some Date Palm Varieties in Baghdad Orchards.” Agri. Biol. J. North America 1 (3): 238-42.

[4] Khalaf, M. Z., Al-Rubeae, H. F., Al-Taweel, A. A., and Naher, F. H. 2013. "First Record of Arabian Rhinoceros Beetle Oryctes agamemnon arabicus Fairmaire on Date Palm Trees in Iraq." Agri. Biol. J. North America 4 (3): 349-51.

[5] Khalaf, M. Z., Naher, F. H., Khudair, M. W., Hamood, J. B., and Khalid, H. S. 2014. "Some Biological and Behavioral Aspects of Arabian Rhinoceros Beetle, Oryctes agamemnon arabicus Fairmaire (Coleoptera: Scarabaedae: Dynastinae) under Iraqi Conditions.” Iraqi J. Agric. Res. 19 (2): 122-33.

[6] Soltani, R. 2010. "The Rhinoceros Beetle Oryctes agamemnon arabicus in Tunisia Current Challenge and Future Perspectives." J. of Tunisia Plant Protection 5 (2): 179-93.

[7] Soltani, R. 2011. "Observations on Biology and Ecology of Oryctes agamemnon arabicus Fairmaire: Date Palm Pest in Tunsia." Presented at the Abstract of Arab Conference of Palm and Dates, December 4-7, 2011, Kingdom of Saudia Arabia.

[8] Abass, A. H. 2000. "Laboratory and Field Observation on Palm Stem Borer Oryctes elegans (Coleoptera: Scarabaeidae)." In Proceedings of the 7th Arab Congress of Plant Protection, 42.

[9] Al-Khawaja, H. K. 1999. "Control of Fruit Stalk Borer Oryctes elegans (Coleoptera Scarabaeidae) by Using Agricultural, Chemical and Biological Methods." Iraqi J. Agric. 4 (1): 20-31.

[10] Khalaf, M. Z., and Al-Taweel, A. A. 2015. "Palm Borers in Iraqi Environment: Species, Damages and Methods of Control." J. Blessed Tree 7 (1): 54-64.

[11] Bedford, G. O. 1973. "Experiments with the Virus Rhabdionvirus oryctes against the Coconut Palm Rhinoceros Beetles Oryctes rhinoceros and Scapanes australis groosepunctatus in New Guinea." J. Inver. Path.
22: 70-4.

[12] Kaaka, W. A. 2009. "Fruit Stalk Borer Oryctes elegans: Palm Pests." Accessed October 27, 2016. http://www.iraqi-datepalms.net. (in Arabic)

[13] Alrouechdi, K. 2000. "Pests Control and Biodiversity Conservation." Presented at the Seventh Arab Congress of Plant Protection, October 22-26, 2000, Amman, Jordan.

[14] Al-Bahi, A., Abu-Qeeleh, I., and Al-Dungla, A. 2000. "A Survey of a Carnie Species Associated with Palm Trees in Sabah South Libya." Presented at the Seventh Arab Congress of Plant Protection, October 22-26, 2000, Amman, Jordan.

[15] Steibaner, M. J. 2003. "Using Ultra-Violet Light Traps to Monitor Autumn Gum Moth, Mnesampela private (Lepidoptera: Geometridae) in South-Eastern Australian." Australian Forestry 66 (4): 279-86.

[16] Khalaf, M. Z., Shbar, A. K., Naher, F. H., Jabbo, N. F., Abdul-Hamza, B. H. B. H., and Sami, R. A. 2012. "Activity of Insect Fauna during the Night in the Palm Orchards of Central Iraq." Journal of Food Science and Engineering 2: 277-82.

[17] Khudhair, M. W., Alrubeai, H. F., Khalaf, M. Z., Shbar, A. K., Hammad, B. S., and Khalid, H. S. 2014. "Occurrence and Distribution of Entomopathogenic Fungi in Iraqi Agro-ecosystem." Int. J. Entomol. Res. 2 (2): 117-24.

[18] ICARDA. 2011. "IPM Date Palm-Palm Borers." In Improved Livelihoods of Small Farmers in Iraq through Integrated Pest Management and Organic Fertilization, edited by Khalaf, M. Z., Ali, A. A., and El-Bouhssini, M. Amman, Jordan: ICARDA, 37.

[19] Morton, R., Tauit, L. D., and Wardhangh, K. G. 1981. "The Analysis and Standardization of Light-Trap Catches of Heliothis armigera (Hubner) and H. punctiger Wollengren (Lepidoptera: Noctuidae)." Bulletin of Entomological Research 71: 207-25.

[20] Ricano, J., Guerri-Agullo, B., Serna-Sarrias, M. J., Rubio-Llorca, G., Asensio, L., Barranco, P., and Lopez-Llorca, L. V. 2013. "Evaluation of the Pathogenicity of Multiple Isolates of Beauveria bassiana (Hypocreales: Clavicipitaceae) on Rhynchophorus ferrugineus (Coleoptera: Dryophthoridae) for the Assessment of a Solid Formulation under Simulated Field Conditions." Florida Entomologist 96 (4): 1311-24.

[21] Ritu, A., Anjali, C., Nidhi, T., Sheetal, P., and Deepak, B. 2012. "Biopesticidal Formulation of Beauveria bassiana Effective against Larvae of Helicoverpa armigera." J. Biofertil. Biopestici. 3 (3): 1-3. 